\title{
Substrate Depth Influences Sedum Plant Community on a Green Roof
}

\author{
Kristin L. Getter ${ }^{1,3}$ and D. Bradley Rowe ${ }^{2}$ \\ Department of Horticulture, Michigan State University, A228 Plant and Soil \\ Sciences Department, East Lansing, MI 48824
}

Additional index words. vegetated roof, stonecrop, eco-roof

\begin{abstract}
Because the waterproofing membrane beneath green roofs is estimated to last at least 45 years, long-term plant performance beyond initial establishment is critical. Plants that survive initially on a green roof may not exist in the long term because of variability in climate and other factors. This study evaluated the effect of green roof substrate depth on substrate moisture, plant stress as measured by chlorophyll fluorescence, and plant community development and survival of 12 Sedum species over 4 years in a midwestern U.S. climate during 4 years of growth. Plugs of 12 species of Sedum were planted on 8 June 2005 and evaluated biweekly for absolute cover (AC). Most species exhibited greater growth and coverage at a substrate depth of $7.0 \mathrm{~cm}$ and $10.0 \mathrm{~cm}$ relative to $4.0 \mathrm{~cm}$. For the species evaluated, substrate depths of at least $7.0 \mathrm{~cm}$ are highly recommended. AC of Sedum was significantly greater at this substrate depth than at $4.0 \mathrm{~cm}$. Mean volumetric moisture content of the three substrate depths followed the same pattern as AC. When averaged over time, the $4.0-\mathrm{cm}$ substrate depth held less moisture than depths of 7.0 or $10.0 \mathrm{~cm}$, whereas the 7.0 - and $10.0-\mathrm{cm}$ substrate depths were statistically the same. Species exhibiting the greatest $\mathrm{AC}$ at all substrate depths were S. floriferum, S. sexangulare, S. spurium 'John Creech', and S. stefco. In general, species that are less suitable at these substrate depths are $S$. 'Angelina', $S$. cauticola 'Lidakense', S. ewersii, S. ochroleucum, and $S$. reflexum 'Blue Spruce'.
\end{abstract}

In $2007,223,666 \mathrm{~m}^{2}\left(2,407,525 \mathrm{ft}^{2}\right)$ of green roofs, or vegetated roofs, were installed in North America representing a 30\% increase over 2006 (Green Roofs for Healthy Cities, 2008). By placing plants on rooftops, the vegetated footprint that was previously destroyed during building construction is at least partially replaced. Increased adoption of this roofing technology may be the result of the many benefits they provide such as improved stormwater management (Carter and Jackson, 2007; Getter et al., 2007; Hilten et al., 2008; Jarrett and Berghage, 2008), energy conservation (Sailor, 2008; Santamouris et al., 2007), mitigation of the urban heat island effect (Takebayashi and Moriyama, 2007), increased longevity of roofing membranes (Kosareo and Ries, 2007), a better return on investment than traditional roofs (Clark et al., 2008), reduced noise and air pollution (Van Renterghem and Botteldooren, 2008; Yang et al., 2008), increased urban biodiversity (Baumann, 2006; Brenneisen, 2006) as well as providing a more aesthetically pleasing environment to experience (Getter and Rowe, 2006; Oberndorfer et al., 2007).

For green roofs to be successful as well as to meet client expectations, plant selection is

\footnotetext{
Received for publication 10 Nov. 2008. Accepted for publication 19 Jan. 2009.

This paper is a portion of a $\mathrm{PhD}$ dissertation submitted by Kristin L. Getter.

${ }^{1}$ Graduate Research Assistant.

${ }^{2}$ Associate Professor.

${ }^{3}$ To whom reprint requests should be addressed; e-mailsmithkri@msu.edu.
}

critical. Species selected must survive extremes in roof microclimate. Green roofs are likely to experience drought and severe fluctuations in root zone temperatures as a result of shallow substrates as well as high temperatures and windy conditions. These conditions combined with heat radiating from the building will likely alter hardiness zones and soil moisture content, thus impacting which species are able to survive.

Successful candidate species for extensive green roofs [i.e., green roofs with substrate depths of $10.0 \mathrm{~cm}$ (3.93 in) or less] must exhibit characteristics such as easy propagation, rapid establishment, and high groundcover density (Dunnett and Kingsbury, 2004; Getter and Rowe, 2006; Snodgrass and Snodgrass, 2006). Low-growing plants that spread and cover the substrate in a short period of time reduce potential erosion problems, inhibit weeds, and provide improved aesthetics. Although rapid coverage is important, the ability of plant species to be selfsustaining reduces the need for future replanting and maintenance. Species that are long-lived, that reseed themselves, or spread vegetatively should continue to provide ample coverage $[60 \%$ or greater, as defined by FLL guidelines (FLL, 1995)] as long as environmental conditions are favorable.

The genus Sedum is a popular choice among extensive green roofing projects as a result of its tolerance for drought (Durhman et al., 2006; Wolf and Lundholm, 2008), shallow substrate adaptability (Durhman et al., 2007; Emilsson, 2008), persistence (Köhler, 2006; Monterusso et al., 2005; Rowe et al., 2006), and ability to limit transpiration (Kluge, 1977; Lee and Kim, 1994), and store water (Gravatt, 2003; Teeri et al., 1986). However, even for such a wellsuited genus, substrate depth can influence the rate of substrate coverage and subsequent plant growth (Durhman et al., 2007; Getter and Rowe, 2008; Rowe et al., 2006). Deeper substrates are beneficial for both increased waterholding capacity (VanWoert et al., $2005 \mathrm{a}, 2005 \mathrm{~b}$ ) and as a buffer in fluctuating winter temperatures (Boivin et al., 2001). Despite the cultural limitations of shallow substrate depths, they are often desirable because of lighter roof loads.

Plant stress resulting from shallow substrate and other conditions on a roof can be recorded by measuring chlorophyll fluorescence. This technique is used to quantify the efficiency of the photosynthetic apparatus (Maxwell and Johnson, 2000). Photon energy absorbed by a chlorophyll molecule can be used to fuel photosynthesis, dissipated as heat, or re-emitted as fluorescence. Measurement of the latter is used to indicate how efficient the former two processes are proceeding. Fluorometers are used to measure this value, usually reporting the ratio $\left(\mathrm{F}_{\mathrm{v}} / \mathrm{F}_{\mathrm{m}}\right)$ of variable fluorescence $\left(F_{v}\right)$ to maximum fluorescence $\left(F_{m}\right)$ that typically ranges from 0.70 to 0.83 with values less than 0.60 indicating photosynthetic stress (Ritchie, 2006).

Many studies for plant survival on green roofs collect data for 1 to 2 years (Durhman et al., 2007; Emilsson and Rolf, 2005; Kircher, 2004; MacDonagh et al., 2006; Nagase and Dunnett, 2008). Because the waterproofing membrane beneath green roofs is estimated to last 45 years or longer (Kosareo and Ries, 2007), long-term plant performance beyond the first few years' growth is important. Plants that survive initially on a green roof may not exist there in the long term because of variability in climate and other factors. Therefore, the objective of this study was to evaluate the effect of substrate depth on substrate moisture, plant stress as measured by chlorophyll fluorescence, and plant community development and survival of 12 Sedum species over a period of 4 years.

\section{Materials and Methods}

Green roof platforms. Three roof platforms with dimensions of $2.44 \mathrm{~m} \times 2.44 \mathrm{~m}$ $(8.0 \mathrm{ft} \times 8.0 \mathrm{ft})$ were used at the Michigan State University Horticulture Teaching and Research Center (East Lansing, MI). Each platform was situated at ground level and replicated a commercial extensive green roof, including insulation, protective and waterproofing membrane layers. Construction details are outlined in VanWoert et al. (2005a).

The wood-framed platforms included sides that extend $20.3 \mathrm{~cm}$ (8.0 in) above the platform deck. Each platform was divided into three equal sections measuring $0.77 \mathrm{~m} \times$ $2.40 \mathrm{~m}(2.53 \mathrm{ft} \times 7.87 \mathrm{ft})$ using wood dividers. The platform sides and dividers were also covered with waterproofing membrane. Each platform was set at a $2 \%$ slope and was placed 
with the low end of the slope facing south to maximize sun exposure.

Drainage system and vegetation carrier. Each platform was constructed with a Xero Flor XF108 drainage mat (Wolfgang Behrens Systementwicklung, GmbH, Groß Ippener, Germany) installed over the waterproofing system, which allows excess water to flow off the roof. For additional waterholding capacity, a $0.75-\mathrm{cm}(0.26-$ in) thick moisture retention fabric (Xero Flor XF159) capable of retaining $5.92 \mathrm{~kg} \cdot \mathrm{m}^{-2}$ of water was placed over the drainage layer followed by the vegetation carrier (Xero Flor XF301). Growing substrate was placed on the vegetation carrier at three different depths $[4.0 \mathrm{~cm}, 7.0 \mathrm{~cm}$, or $10.0 \mathrm{~cm}$ $(1.6,2.8$, and 3.9 in)]. Initially, the substrate consisted of $86 \%$ sand, $10 \%$ silt, and $4 \%$ clay and had a bulk density of $1.37 \mathrm{~g} \cdot \mathrm{cm}^{-3}$ and a waterholding capacity at $0.01 \mathrm{MPa}$ of $16.05 \%$. Further details of the initial physical and chemical properties of the substrate are detailed in Getter and Rowe (2008).

Plant species. The 12 species tested included Sedum 'Angelina' (crooked stonecrop), Sedum cauticola 'Lidakense' (stonecrop), Sedum ewersii (stonecrop), Sedum floriferum (kamtschatka stonecrop), Sedum hispanicum (Spanish stonecrop), Sedum ochroleucum (European stonecrop), Sedum reflexum 'Blue Spruce' (crooked stonecrop), Sedum sarmentosum (stringy stonecrop), Sedum sediforme (pale stonecrop), Sedum sexangulare (tasteless stonecrop), Sedum spurium 'John
Creech' (creeping sedum), and Sedum stefco (stonecrop). Plants were obtained from Emory Knoll Farms (Street, MD) as plugs $\left(120 \mathrm{~cm}^{3}\right.$; $72 /$ flat) that were established in a standard propagation mix of peat, perlite, and vermiculite (Super-Fine Germination Media; Farfard, Inc., Agawam, MA). Plugs were planted on 8 June 2005 with four plants in 12 rows. Each species was planted four times randomly in each section resulting in plugs spaced $17.0 \mathrm{~cm}$ (6.7 in) apart from each other and platform walls. All plots were fertilized [Nutricote controlled-release fertilizer $18 \mathrm{~N}-6 \mathrm{P}-8 \mathrm{~K}$ type 120 (Agrivert, Webster, TX) at $100.0 \mathrm{~g} \cdot \mathrm{m}^{-2}$ ] and watered to field capacity by hand on the day of planting. No further irrigation was provided.

Table 1. Mean absolute cover \pm SDs of 12 Sedum species cultivated at three substrate depths $(4.0,7.0$, and $10.0 \mathrm{~cm})$ at the end of four growing seasons (2005 to 2008).

\begin{tabular}{|c|c|c|c|c|}
\hline \multirow[b]{2}{*}{ Species } & \multicolumn{4}{|c|}{ Absolute cover $(\text { depth }=4.0 \mathrm{~cm})^{z}$} \\
\hline & Week 15 & Week 67 & Week 120 & Week 172 \\
\hline S. Angelina & $0.0052 \pm 0.0045$ a $\mathrm{ABC}$ & $0.0182 \pm 0.0045 \mathrm{~b} \mathrm{BC}$ & $0.0104 \pm 0.0119 \mathrm{ab} \mathrm{AB}$ & $0.0052 \pm 0.0045 \mathrm{a} \mathrm{AB}$ \\
\hline S. cauticola Lidakense & $0.0000 \pm 0.0000 \mathrm{a} \mathrm{A}$ & $0.0000 \pm 0.0000 \mathrm{a} \mathrm{A}$ & $0.0000 \pm 0.0000 \mathrm{a} \mathrm{A}$ & $0.0000 \pm 0.0000 \mathrm{a} \mathrm{A}$ \\
\hline S. ewersii & $0.0000 \pm 0.0000 \mathrm{a} \mathrm{A}$ & $0.0130 \pm 0.0226 \mathrm{a} \mathrm{AB}$ & $0.0104 \pm 0.0180 \mathrm{a} \mathrm{AB}$ & $0.0182 \pm 0.0316 \mathrm{a} \mathrm{AB}$ \\
\hline S. floriferum & $0.0130 \pm 0.0163 \mathrm{a} \mathrm{BC}$ & $0.1016 \pm 0.0135 \mathrm{~b} \mathrm{DE}$ & $0.1979 \pm 0.0726 \mathrm{~b} \mathrm{C}$ & $0.2891 \pm 0.0639 \mathrm{~b} \mathrm{C}$ \\
\hline S. hispanicum & $0.0000 \pm 0.0000 \mathrm{a} A$ & $0.0469 \pm 0.0282 \mathrm{~b} \mathrm{CD}$ & $0.0234 \pm 0.0207 \mathrm{~b} \mathrm{~B}$ & $0.0391 \pm 0.0435 \mathrm{~b} \mathrm{~B}$ \\
\hline S. ochroleucum & $0.0026 \pm 0.0045 \mathrm{ab} \mathrm{AB}$ & $0.0078 \pm 0.0078 \mathrm{~b} \mathrm{AB}$ & $0.0000 \pm 0.0000 \mathrm{a} \mathrm{A}$ & $0.0000 \pm 0.0000 \mathrm{a} \mathrm{A}$ \\
\hline S. reflexum Blue Spruce & $0.0000 \pm 0.0000 \mathrm{a} \mathrm{A}$ & $0.0208 \pm 0.0180 \mathrm{~b} \mathrm{BC}$ & $0.0234 \pm 0.0207 \mathrm{~b} \mathrm{~B}$ & $0.0104 \pm 0.0045 \mathrm{~b} \mathrm{AB}$ \\
\hline S. sarmentosum & $0.0729 \pm 0.0163 \mathrm{c} \mathrm{D}$ & $0.0130 \pm 0.0119 \mathrm{~b} \mathrm{AB}$ & $0.0000 \pm 0.0000 \mathrm{a} \mathrm{A}$ & $0.0000 \pm 0.0000 \mathrm{a} \mathrm{A}$ \\
\hline S. sediforme & $0.0052 \pm 0.0045 \mathrm{~b} \mathrm{ABC}$ & $0.0000 \pm 0.0000 \mathrm{a} \mathrm{A}$ & $0.0000 \pm 0.0000 \mathrm{a} \mathrm{A}$ & $0.0000 \pm 0.0000 \mathrm{a} \mathrm{A}$ \\
\hline S. sexangulare & $0.0104 \pm 0.0119 \mathrm{a} \mathrm{BC}$ & $0.1120 \pm 0.0296 \mathrm{~b} \mathrm{DE}$ & $0.2214 \pm 0.0813 \mathrm{~b} \mathrm{C}$ & $0.2031 \pm 0.0979 \mathrm{~b} \mathrm{C}$ \\
\hline S. spurium John Creech & $0.0182 \pm 0.0119$ a CD & $0.1172 \pm 0.0413 \mathrm{~b} \mathrm{DE}$ & $0.1719 \pm 0.0668 \mathrm{~b} \mathrm{C}$ & $0.2318 \pm 0.0592 \mathrm{~b} \mathrm{C}$ \\
\hline \multirow[t]{2}{*}{ S. stefco } & $0.0130 \pm 0.0045$ a C & $0.2292 \pm 0.0627 \mathrm{~b} \mathrm{E}$ & $0.3698 \pm 0.0325 \mathrm{~b} \mathrm{C}$ & $0.3984 \pm 0.0547 \mathrm{~b} \mathrm{C}$ \\
\hline & \multicolumn{4}{|c|}{ Absolute cover $(\text { depth }=7.0 \mathrm{~cm})^{\mathrm{y}}$} \\
\hline Species & Week 15 & Week 67 & Week 120 & Week 172 \\
\hline S. Angelina & $0.0078 \pm 0.0078 \mathrm{a} \mathrm{AB}$ & $0.0599 \pm 0.0239 \mathrm{~b} \mathrm{DE}$ & $0.0339 \pm 0.0197 \mathrm{~b} \mathrm{~B}$ & $0.0104 \pm 0.0119$ a B \\
\hline S. cauticola Lidakense & $0.0052 \pm 0.0045 \mathrm{~b} \mathrm{AB}$ & $0.0000 \pm 0.0000 \mathrm{a} \mathrm{A}$ & $0.0000 \pm 0.0000 \mathrm{a} \mathrm{A}$ & $0.0000 \pm 0.0000 \mathrm{aA}$ \\
\hline S. ewersii & $0.0156 \pm 0.0156 \mathrm{ab} \mathrm{BC}$ & $0.0312 \pm 0.0207 \mathrm{~b}$ CD & $0.0286 \pm 0.0369 \mathrm{ab} B$ & $0.0130 \pm 0.0119$ a B \\
\hline S. floriferum & $0.0443 \pm 0.0090 \mathrm{a} \mathrm{DE}$ & $0.1536 \pm 0.0180 \mathrm{~b} \mathrm{EF}$ & $0.2760 \pm 0.0502 \mathrm{~b} \mathrm{C}$ & $0.3880 \pm 0.0296 \mathrm{~b} \mathrm{D}$ \\
\hline S. hispanicum & $0.0156 \pm 0.0156 \mathrm{~b} \mathrm{BC}$ & $0.0156 \pm 0.0078 \mathrm{~b} \mathrm{BC}$ & $0.0000 \pm 0.0000 \mathrm{a} \mathrm{A}$ & $0.0000 \pm 0.0000 \mathrm{aA}$ \\
\hline S. ochroleucum & $0.0026 \pm 0.0045 \mathrm{a} \mathrm{A}$ & $0.0182 \pm 0.0045 \mathrm{~b}$ BCD & $0.0000 \pm 0.0000 \mathrm{a} \mathrm{A}$ & $0.0000 \pm 0.0000 \mathrm{aA}$ \\
\hline S. reflexum Blue Spruce & $0.0026 \pm 0.0045 \mathrm{a} \mathrm{A}$ & $0.0391 \pm 0.0135$ b CD & $0.0234 \pm 0.0000 \mathrm{~b} \mathrm{~B}$ & $0.0000 \pm 0.0000 \mathrm{a} \mathrm{A}$ \\
\hline S. sarmentosum & $0.1641 \pm 0.0156 \mathrm{~b} \mathrm{E}$ & $0.5286 \pm 0.1329 \mathrm{~b} \mathrm{~F}$ & $0.2031 \pm 0.0812 \mathrm{~b} \mathrm{C}$ & $0.0443 \pm 0.0325 \mathrm{a} \mathrm{C}$ \\
\hline S. sediforme & $0.0026 \pm 0.0045 \mathrm{ab} A$ & $0.0104 \pm 0.0090 \mathrm{~b} \mathrm{~B}$ & $0.0000 \pm 0.0000 \mathrm{a} \mathrm{A}$ & $0.0000 \pm 0.0000 \mathrm{aA}$ \\
\hline S. sexangulare & $0.0208 \pm 0.0045$ a CD & $0.1745 \pm 0.0430 \mathrm{~b}$ EF & $0.2891 \pm 0.0207 \mathrm{~b} \mathrm{C}$ & $0.2839 \pm 0.0163 \mathrm{~b} \mathrm{D}$ \\
\hline S. spurium John Creech & $0.0260 \pm 0.0119$ a CD & $0.1458 \pm 0.0197 \mathrm{~b}$ EF & $0.3385 \pm 0.0180 \mathrm{~b} \mathrm{C}$ & $0.3802 \pm 0.0251 \mathrm{~b} \mathrm{D}$ \\
\hline \multirow[t]{2}{*}{ S. stefco } & $0.0260 \pm 0.0197$ a CD & $0.2161 \pm 0.0722 \mathrm{~b} \mathrm{EF}$ & $0.2552 \pm 0.0705 \mathrm{~b} \mathrm{C}$ & $0.2396 \pm 0.0759 \mathrm{~b} \mathrm{D}$ \\
\hline & \multicolumn{4}{|c|}{ Absolute cover $(\text { depth }=10.0 \mathrm{~cm})^{\mathrm{x}}$} \\
\hline Species & Week 15 & Week 67 & Week 120 & Week 172 \\
\hline S. Angelina & $0.0052 \pm 0.0090 \mathrm{a} \mathrm{AB}$ & $0.0469 \pm 0.0207 \mathrm{~b}$ BCD & $0.0078 \pm 0.0135 \mathrm{a} \mathrm{AB}$ & $0.0104 \pm 0.0119$ a B \\
\hline S. cauticola Lidakense & $0.0000 \pm 0.0000 \mathrm{a} \mathrm{A}$ & $0.0000 \pm 0.0000 \mathrm{a} \mathrm{A}$ & $0.0000 \pm 0.0000 \mathrm{a} \mathrm{A}$ & $0.0000 \pm 0.0000 \mathrm{aA}$ \\
\hline S. ewersii & $0.0104 \pm 0.0119 \mathrm{a} \mathrm{BC}$ & $0.0339 \pm 0.0119 \mathrm{~b} \mathrm{BC}$ & $0.0130 \pm 0.0119$ a B & $0.0078 \pm 0.0135 \mathrm{a} \mathrm{A}$ \\
\hline S. floriferum & $0.0677 \pm 0.0119 \mathrm{a} \mathrm{DE}$ & $0.1979 \pm 0.0709 \mathrm{ab} \mathrm{DE}$ & $0.4219 \pm 0.0870 \mathrm{~b} \mathrm{C}$ & $0.5599 \pm 0.0502 \mathrm{~b} \mathrm{C}$ \\
\hline S. hispanicum & $0.0182 \pm 0.0045$ с CD & $0.0052 \pm 0.0045 \mathrm{~b} \mathrm{~A}$ & $0.0339 \pm 0.0401 \mathrm{bc} \mathrm{B}$ & $0.0000 \pm 0.0000 \mathrm{a} \mathrm{A}$ \\
\hline S. ochroleucum & $0.0026 \pm 0.0045 \mathrm{a} \mathrm{AB}$ & $0.0000 \pm 0.0000 \mathrm{aA}$ & $0.0000 \pm 0.0000 \mathrm{a} \mathrm{A}$ & $0.0000 \pm 0.0000 \mathrm{a} \mathrm{A}$ \\
\hline S. reflexum Blue Spruce & $0.0026 \pm 0.0045 \mathrm{ab} \mathrm{AB}$ & $0.0286 \pm 0.0226 \mathrm{c} \mathrm{B}$ & $0.0104 \pm 0.0090 \mathrm{~b} \mathrm{~B}$ & $0.0000 \pm 0.0000 \mathrm{a} \mathrm{A}$ \\
\hline S. sarmentosum & $0.1745 \pm 0.0369 \mathrm{~b} \mathrm{E}$ & $0.6641 \pm 0.1369 \mathrm{c} \mathrm{E}$ & $0.1693 \pm 0.1466$ b C & $0.0521 \pm 0.0709$ a B \\
\hline S. sediforme & $0.0026 \pm 0.0045 \mathrm{ab} \mathrm{AB}$ & $0.0052 \pm 0.0045 \mathrm{~b} \mathrm{~A}$ & $0.0000 \pm 0.0000 \mathrm{a} \mathrm{A}$ & $0.0000 \pm 0.0000 \mathrm{a} \mathrm{A}$ \\
\hline S. sexangulare & $0.0365 \pm 0.0119$ a D & $0.1406 \pm 0.0078 \mathrm{~b} \mathrm{CD}$ & $0.2292 \pm 0.0759 \mathrm{~b} \mathrm{C}$ & $0.1901 \pm 0.0554 \mathrm{~b} \mathrm{C}$ \\
\hline S. spurium John Creech & $0.0286 \pm 0.0090$ a D & $0.1484 \pm 0.0078$ b DE & $0.3333 \pm 0.0576 \mathrm{~b} \mathrm{C}$ & $0.3333 \pm 0.0726 \mathrm{~b} \mathrm{C}$ \\
\hline S. stefco & $0.0547 \pm 0.0135 \mathrm{a} \mathrm{DE}$ & $0.1849 \pm 0.1331 \mathrm{ab} \mathrm{DE}$ & $0.2474 \pm 0.1641 \mathrm{~b} \mathrm{C}$ & $0.1875 \pm 0.1447 \mathrm{ab} \mathrm{C}$ \\
\hline
\end{tabular}

${ }^{z}$ Cover reported in weeks, in which Week 15=23 Sept. 2005; Week 67 =19 Sept. 2006; Week 120=24 Sept. 2007; Week 172 = 25 Sept. 2008. Absolute cover was calculated for each species at each substrate depth as the total number of point frame contacts divided by the number of data collection points. Mean separation in rows and columns for each species by least significant difference $(P \leq 0.05)$. Lowercase letters in rows denote comparisons over time within individual substrate depths and species $(\mathrm{n}=12)$. Uppercase letters in columns denote differences among species $(\mathrm{n}=12)$. SE was \pm 0.0975 and \pm 0.1757 for rows and columns, respectively.

${ }^{y}$ Mean separation in rows and columns for each species by least significant difference $(P \leq 0.05)$. Lowercase letters in rows denote comparisons over time within individual substrate depths and species $(\mathrm{n}=12)$. Uppercase letters in columns denote differences among species $(\mathrm{n}=12)$. $\mathrm{sE}$ was \pm 0.0763 and \pm 0.1376 for rows and columns, respectively.

${ }^{\mathrm{x}}$ Mean separation in rows and columns for each species by least significant difference $(P \leq 0.05)$. Lowercase letters in rows denote comparisons over time within individual substrate depths and species $(\mathrm{n}=12)$. Uppercase letters in columns denote differences among species $(\mathrm{n}=12)$. SE was \pm 0.0856 and \pm 0.1543 for rows and columns, respectively. 
This planting arrangement resulted in a split-plot design that was arranged in randomized complete blocks with two factors replicated three times. The main plot was substrate depth [4.0, 7.0, and $10.0 \mathrm{~cm}(1.6,2.8$, and 3.9 in)] and the subplot factor was plant species, which had 12 treatments, each replicated four times within a subplot for a total of 48 plants per substrate depth per plot.

Data collection and analysis. A transect (a stainless steel point frame) was used every 2 weeks during the first three growing seasons and monthly in the fourth growing season to measure community composition and change (Waite, 2000). The point frame had internal measurements of $0.77 \mathrm{~m} \times 1.2 \mathrm{~m}(2.5 \mathrm{ft} \times 3.9$ $\mathrm{ft}$ ) and had eight strings (50 pound Berkley Gorilla Super Braid Fishing Line; Berkley, Spirit Lake, IA) vertically and eight strings horizontally to create 64 measurement points. The point frame sat directly on top of the platform sides secured by finishing nails that allowed the frame to be positioned in the exact same spot every time. A stainless steel skewer was placed vertically at each measuring point and each species the skewer contacted was recorded up to three canopy layers.

Substrate moisture and chlorophyll fluorescence data were collected throughout the last two growing seasons. Substrate moisture measurements were monitored by inserting a theta probe (ML2x; Delta-T Devices, Ltd., Cambridge, U.K.) with 6.0-cm (2.4-in) rods into the media until they were completely buried. Measurements were collected at random times each week in triplicate in each subplot. Chlorophyll fluorescence measurements were collected at six different times (21 May 2007, 18 June 2007, 2 Aug. 2007, 17 Sept. 2007, 29 May 2008, and 20 Aug. 2008) using a Hansatech plant efficiency analyzer (PEA; Hansatech Instruments, Ltd., Norfolk, U.K.). These measurement dates were selected to cover a wide range of environmental conditions, including active growth and drought stress during the growing season. Leaves from each plant were dark-adapted for $20 \mathrm{~min}$ before measurement. Maximum quantum efficiency of photosystem II was recorded $\left(\mathrm{F}_{\mathrm{v}} / \mathrm{F}_{\mathrm{m}}\right)$. Three single leaf blades of each surviving species were randomly selected in each subplot and excised from the plant to be dark-adapted and measured. This was necessary because the PEA clips were not secure on the leaf of most species while still attached to the whole plant.

Data analysis. Absolute cover (AC) was calculated for each species at each substrate depth as the total number of contacts recorded divided by the number of data collection points. Data were then analyzed as mean AC using repeated measures. Although original means are presented, all $\mathrm{AC}$ values were transformed before analysis using a log transformation to stabilize the variance and normalize the data set (Underwood, 1998). Significant differences between treatments were determined using multiple comparisons (PROC MIXED, SAS Version 8.02; SAS Institute, Cary, NC). In addition, mean substrate volumetric moisture content and mean chlorophyll fluorescence data were analyzed by PROC MIXED, least significant differences (SAS Version 8.02; SAS Institute).

\section{Results and Discussion}

Four points in time (Weeks 15, 67, 120, and 172) were chosen for comparing growth that represent the end of each growing season (before first frost). At a substrate depth of 4.0 $\mathrm{cm}$, four species exhibited no significant growth between the end of the first and fourth growing seasons ( $S$. 'Angelina', $S$. cauticola 'Lidakense', S. ewersii, and S. ochroleucum), whereas at $7.0 \mathrm{~cm}$, five species $(S$. 'Angel- ina', $S$. ewersii, $S$. ochroleucum, $S$. reflexum 'Blue Spruce', and $S$. sediforme) fit this category (Table 1; Fig. 1). At the $10.0-\mathrm{cm}$ substrate depth, there were six such species ( $S$. 'Angelina', S. cauticola 'Lidakense', $S$. ewersii, $S$. ochroleucum, $S$. reflexum 'Blue Spruce', and $S$. sediforme). As a result, at their respective substrate depths, all of these species have zero or near zero AC by Week 172 .

At each substrate depth, there were also species that decreased in $\mathrm{AC}$ across the four growing seasons, also resulting in zero $\mathrm{AC}$ by Week 172 (Table 1; Fig. 1). At substrate depths of $4.0 \mathrm{~cm}(S$. sarmentosum and $S$. sediforme) and $10.0 \mathrm{~cm}$ (S. hispanicum and $S$.
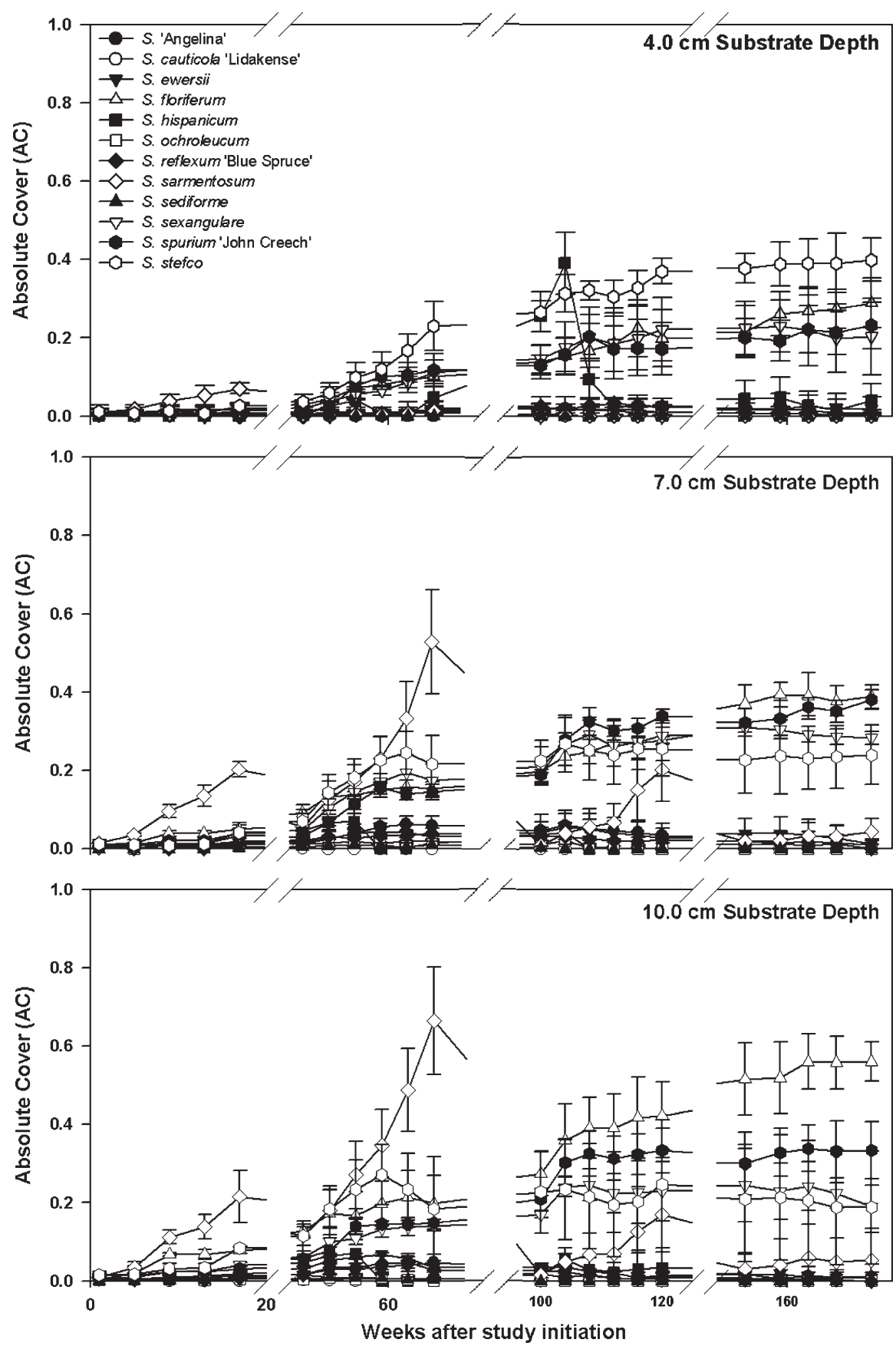

Fig. 1. Absolute cover \pm SDs of 12 Sedum spp. cultivated at three substrate depths $(4.0,7.0$, and $10.0 \mathrm{~cm})$ over the 2005 to 2008 growing seasons. Symbols represent absolute cover means with SDs $(n=3)$. For clarity of graphing, Weeks 0 through 120 were plotted at every other data point. 


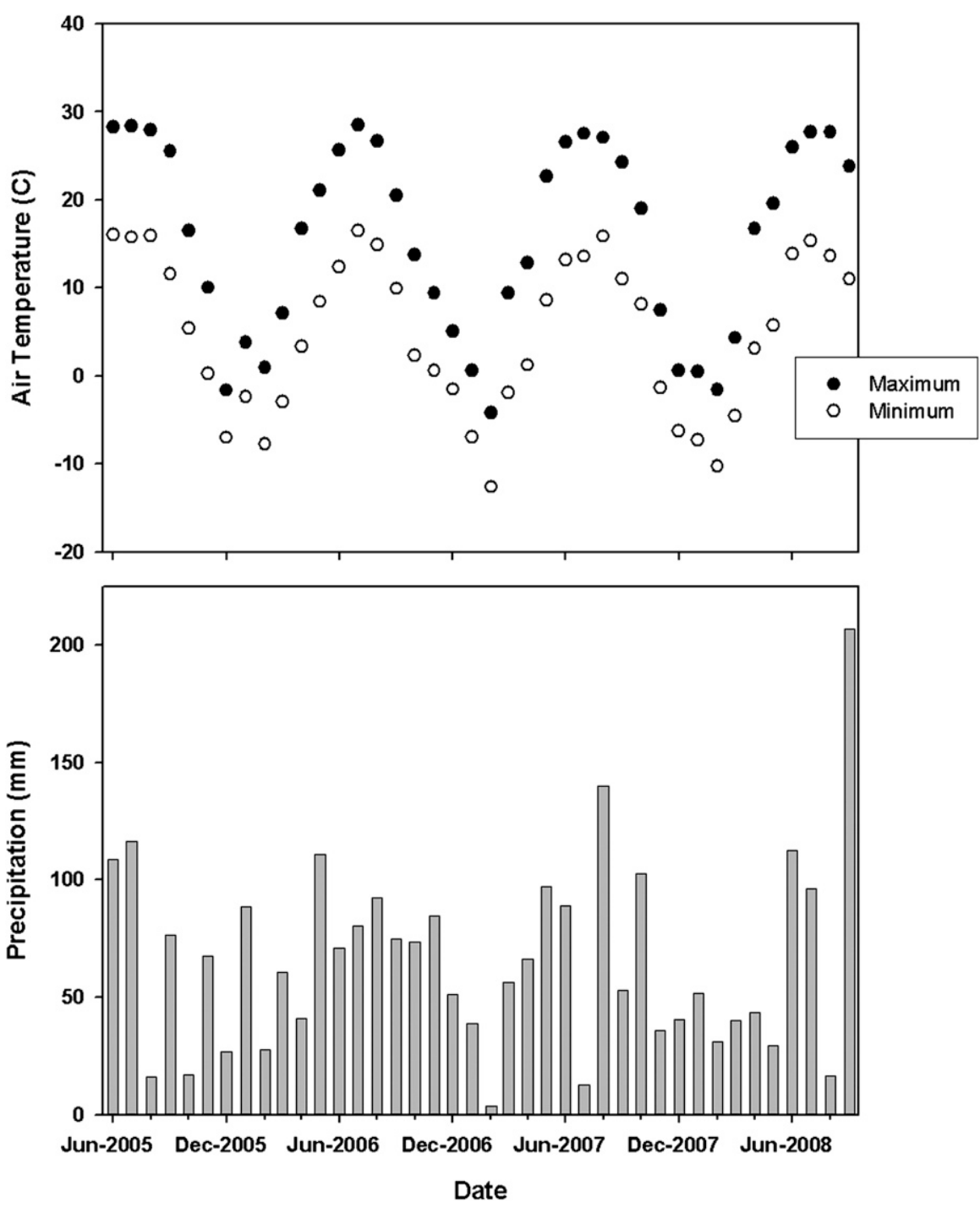

Fig. 2. Monthly average maximum air temperatures $\left({ }^{\circ} \mathrm{C}\right)$, monthly average minimum air temperatures $\left({ }^{\circ} \mathrm{C}\right)$, and monthly total precipitation $(\mathrm{mm})$ throughout the study (1 June 2005 to 30 Sept. 2008). Data are from the Michigan Automated Weather Network's East Lansing weather station (located adjacent to the research site)

Table 2. Mean absolute cover \pm SDs of 12 Sedum species cultivated at three substrate depths (4.0, 7.0, and $10.0 \mathrm{~cm}$ ) reported on Week 172 (25 Sept. 2008). ${ }^{\mathrm{z}}$

\begin{tabular}{lccc}
\hline & \multicolumn{3}{c}{ Absolute cover (Week 172) } \\
\cline { 2 - 4 } Species & $4.0 \mathrm{~cm}$ & $7.0 \mathrm{~cm}$ & $10.0 \mathrm{~cm}$ \\
\hline S. Angelina & $0.0052 \pm 0.0045 \mathrm{a}$ & $0.0104 \pm 0.0119 \mathrm{a}$ & $0.0104 \pm 0.0119 \mathrm{a}$ \\
S. cauticola Lidakense & $0.0000 \pm 0.0000 \mathrm{a}$ & $0.0000 \pm 0.0000 \mathrm{a}$ & $0.0000 \pm 0.0000 \mathrm{a}$ \\
S. ewersii & $0.0182 \pm 0.0316 \mathrm{a}$ & $0.0130 \pm 0.0119 \mathrm{a}$ & $0.0078 \pm 0.0135 \mathrm{a}$ \\
S. floriferum & $0.2891 \pm 0.0639 \mathrm{a}$ & $0.3880 \pm 0.0296 \mathrm{~b}$ & $0.5599 \pm 0.0502 \mathrm{c}$ \\
S. hispanicum & $0.0391 \pm 0.0435 \mathrm{a}$ & $0.0000 \pm 0.0000 \mathrm{a}$ & $0.0000 \pm 0.0000 \mathrm{a}$ \\
S. ochroleucum & $0.0000 \pm 0.0000 \mathrm{a}$ & $0.0000 \pm 0.0000 \mathrm{a}$ & $0.0000 \pm 0.0000 \mathrm{a}$ \\
S. reflexum Blue Spruce & $0.0104 \pm 0.0045 \mathrm{a}$ & $0.0000 \pm 0.0000 \mathrm{a}$ & $0.0000 \pm 0.0000 \mathrm{a}$ \\
S. sarmentosum & $0.0000 \pm 0.0000 \mathrm{a}$ & $0.0443 \pm 0.0325 \mathrm{a}$ & $0.0521 \pm 0.0709 \mathrm{a}$ \\
S. sediforme & $0.0000 \pm 0.0000 \mathrm{a}$ & $0.0000 \pm 0.0000 \mathrm{a}$ & $0.0000 \pm 0.0000 \mathrm{a}$ \\
S. sexangulare & $0.2031 \pm 0.0979 \mathrm{a}$ & $0.2839 \pm 0.0163 \mathrm{~b}$ & $0.1901 \pm 0.0554 \mathrm{a}$ \\
S. spurium John Creech & $0.2318 \pm 0.0592 \mathrm{a}$ & $0.3802 \pm 0.0251 \mathrm{~b}$ & $0.3333 \pm 0.0726 \mathrm{~b}$ \\
S. stefco & $0.3984 \pm 0.0547 \mathrm{~b}$ & $0.2396 \pm 0.0759 \mathrm{a}$ & $0.1875 \pm 0.1447 \mathrm{a}$ \\
\hline
\end{tabular}

${ }^{\mathrm{z}}$ Absolute cover was calculated for each species at each substrate depth as the total number of point frame contacts divided by the number of data collection points. Mean separation in rows for each species by least significant difference $(P \leq 0.05)$. Lowercase letters denote comparisons within the same row $(\mathrm{n}=12)$ with $\mathrm{SE} \pm 0.0146$

sarmentosum), there were two such species. The 7.0-cm substrate depth had three species (S. cauticola 'Lidakense', S. hispanicum, and S. sarmentosum). rum, S. sexangulare, $S$. spurium 'John Creech', and $S$. stefco ) with the $4.0-\mathrm{cm}$ substrate depth having an additional two species (S. hispanicum and S. reflexum 'Blue Spruce'). For all species, the increase in $\mathrm{AC}$ was only significant between the first and second growing seasons. This perhaps indicates that by the end of the second growing season, the plant community had reached a mature or stable state.

Results for the first growing season, as previously published, demonstrated that by the end of the first growing season (Week 19 ) at all three substrate depths, $S$. sarmentosum exhibited a much higher AC than all other species (Getter and Rowe, 2008; Fig. 1). However, subsequent growing seasons produced very different results, highlighting the importance of long-term studies. For the 4.0$\mathrm{cm}$ substrate depth, this species remained at near zero $\mathrm{AC}$ for the remaining growing seasons. At the $7.0-\mathrm{cm}$ and $10.0-\mathrm{cm}$ substrate depths, however, this species represents more than half of the coverage by the end of the second growing season, has a slow recovery in the third growing season to represent nearly $20 \%$ of coverage, but then falls to near zero $\mathrm{AC}$ at the end of the fourth growing season.

It is possible that the reason for $S$. sarmentosum's eventual failure at all three substrate depths is the result of incorrect hardiness zone classification for this species. Minimum air temperatures were lower during the second winter $\left(-22.0^{\circ} \mathrm{C}\right)$ and had a longer duration of extreme cold ( $33 \mathrm{~d}$ less than -10 $\left.{ }^{\circ} \mathrm{C}\right)$ as compared with the first winter $(-19.9$ ${ }^{\circ} \mathrm{C}$; $20 \mathrm{~d}$ less than $-10{ }^{\circ} \mathrm{C}$ ) in which this species successfully recovered (Fig. 2). East Lansing, MI, is classified as Zone 5 on the USDA plant-hardiness map, a value corresponding to an average minimum temperature between -26 and $-29^{\circ} \mathrm{C}\left(-20\right.$ to $\left.-10^{\circ} \mathrm{F}\right)$ (Cathey, 1990). Plants that are classified with hardiness zones less than or equal to a geographical area should in theory survive in that climate (assuming all other plant requirements are met). Sedum sarmentosum is categorized as a Zone 5 species (Snodgrass and Snodgrass, 2006), but typically species are assigned a hardiness zone based on observation only or based on how related species have performed in the past. Hardiness zones are also meant for plants growing at ground level. Although initial work with this species indicated that it was able to overwinter successfully when given enough establishment time before first frost (Getter and Rowe, 2007), this current study shows that $S$. sarmentosum is likely unsuitable for this climate. In climates with warmer winters, it is possible that this species may cover a majority of the roof, as suggested by first-year data here. However, this situation poses a threat in that an unusual cold spell may completely wipe out $S$. sarmentosum resulting in many bare spots on the roof.

Differences in growth as measured by AC across the sampled substrate depths and time may be partially explained by the habit of the species themselves. Some species such as $S$. 'Angelina', S. cauticola 'Lidakense', $S$. 
Table 3. Mean absolute cover \pm SDs averaged over species cultivated at three substrate depths (4.0, 7.0 , and $10.0 \mathrm{~cm})$ over the 2005 to 2008 growing seasons. ${ }^{\mathrm{z}}$

\begin{tabular}{|c|c|c|c|c|}
\hline \multirow[b]{2}{*}{ Depth } & \multicolumn{4}{|c|}{ Absolute cover } \\
\hline & Week 15 & Week 67 & Week 120 & Week 172 \\
\hline $4.0 \mathrm{~cm}$ & $0.1406 \pm 0.0282$ a A & $0.6797 \pm 0.2115$ a A & $1.0286 \pm 0.1864 \mathrm{~b} \mathrm{~A}$ & $1.1953 \pm 0.1151 \mathrm{c} \mathrm{A}$ \\
\hline $7.0 \mathrm{~cm}$ & $0.3333 \pm 0.0119$ a A & $1.3932 \pm 0.0722$ bc B & $1.4479 \pm 0.0798 \mathrm{~b} \mathrm{~B}$ & $1.3594 \pm 0.0078 \mathrm{c} \mathrm{B}$ \\
\hline $10.0 \mathrm{~cm}$ & $0.4036 \pm 0.0508$ a A & $1.4557 \pm 0.0607 \mathrm{~b} \mathrm{~B}$ & $1.4661 \pm 0.0369 \mathrm{~b} \mathrm{~B}$ & $1.3411 \pm 0.0430 \mathrm{c} \mathrm{B}$ \\
\hline
\end{tabular}

${ }^{2}$ Cover reported in weeks, in which Week 15=23 Sept. 2005; Week 67=19 Sept. 2006; Week 120=24 Sept. 2007; Week 172=25 Sept. 2008. Absolute cover was calculated for each species at each substrate depth as the total number of point frame contacts divided by the number of data collection points. Mean separation in rows for each depth by least significant difference $(P \leq 0.05)$. Lowercase letters denote comparisons over time within individual substrate depths $(\mathrm{n}=12)$. Uppercase letters in columns denote differences among depths $(\mathrm{n}=12)$. SE was \pm 0.0251 and \pm 0.0904 for rows and columns, respectively.

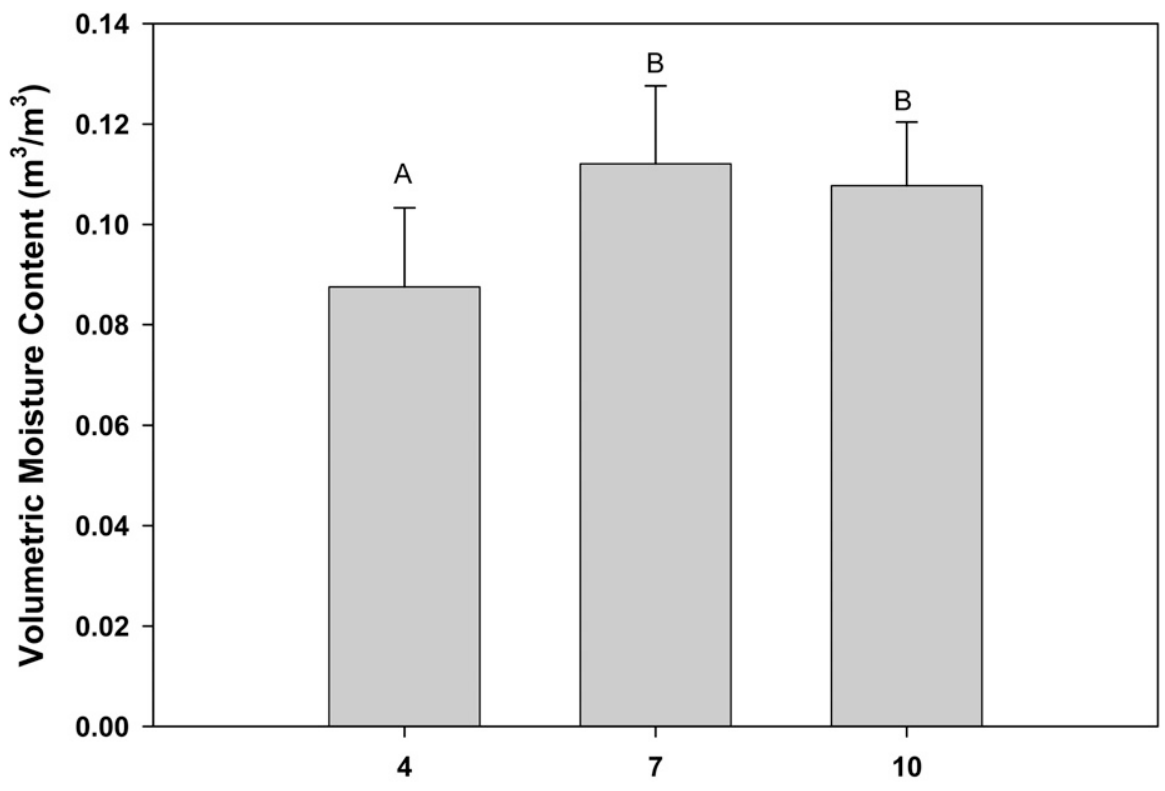

Substrate Depth $(\mathrm{cm})$

Fig. 3. Substrate volumetric moisture content $\left(\mathrm{m}^{3} / \mathrm{m}^{3}\right) \pm$ SEs for three substrate depths (4.0, 7.0, and 10.0 $\mathrm{cm}$ ) averaged over two growing seasons (2007 and 2008). Uppercase letters represent mean separation by least significant difference $(P \leq 0.05)$.

ochroleucom, S. reflexum 'Blue Spruce', and $S$. sediforme are more erect in nature and therefore may be underrepresented in point frame sampling techniques (Wilson, 1960). Furthermore, some species vegetatively reproduce easier than others, allowing them to cover more area than simple growth would allow. Within this genus, Stephenson (2002) reports that increasing degrees of succulence are correlated with improved ability of a species to reproduce asexually (such as $S$. stefco, $S$. sexangulare, and to some extent $S$. sarmentosum). Some species also seem to allocate more energy to sexual reproduction (such as $S$. hispanicum), whereas others allocate more energy to creeping growth (such as S. sarmentosum, which has sterile flowers).

At all substrate depths, by the end of the fourth growing season (Week 172), the same four species ( $S$. floriferum, $S$. sexangulare, $S$. spurium 'John Creech', and S. stefco) consistently exhibited the greatest AC (Table 2). However, relative abundance differed between substrate depths. For example, S. stefco was most abundant at the $4.0-\mathrm{cm}$ substrate depth followed by $S$. floriferum, S. spurium 'John Creech', and S. sexangulare. By contrast, at 7.0 $\mathrm{cm}$ and $10.0 \mathrm{~cm}, S$. floriferum was most abundant followed by S. spurium 'John Creech', S. sexangulare, and S. stefco.
These same four species are also the only four species that were influenced by substrate depth at the end of four growing seasons (Week 172; Table 2). Sedum floriferum is the only species exhibiting significant differences in AC at all three substrate depths. The remaining three species primarily see the difference between $4.0 \mathrm{~cm}$ and $7.0 \mathrm{~cm}$, but not between $7.0 \mathrm{~cm}$ and $10.0 \mathrm{~cm}$.

When AC is averaged over species, all depths demonstrated a statistically significant increase in AC across time (Table 3). AC for the $4.0-\mathrm{cm}$ substrate depth increased from 0.1406 at Week 15 to 1.1953 at Week 172 , whereas AC for the 10.0-cm substrate depth increased from 0.4036 to 1.3411 . With the exception of Week 15, the other times all showed significant substrate depth effects within sampled times, but only between 4.0 $\mathrm{cm}$ and $7.0 \mathrm{~cm}$, not between $7.0 \mathrm{~cm}$ and 10.0 $\mathrm{cm}$. This indicates that for the surviving and most abundant species, substrate depths greater than $7.0 \mathrm{~cm}$ gain no benefit in terms of abundance as measured with a point frame. However, at deeper substrate depths, these plants would likely be healthier, contain greater biomass, and be less susceptible to adverse environmental conditions.

Mean volumetric moisture content of the three substrate depths follows the same pat- tern as AC (Fig. 3). Although extremely variable, when averaged over time, the 4.0$\mathrm{cm}$ substrate depth held less moisture than the $7.0-$ or $10.0-\mathrm{cm}$ depths. The $7.0-$ and $10.0-\mathrm{cm}$ substrate depths were statistically the same. The observation that deeper extensive green roof substrates consistently had higher moisture content than shallower substrates is consistent with similar studies (Liesecke, 1998; VanWoert et al., 2005a, 2005b). In addition, it appears that initially after a rain event, the $4.0-\mathrm{cm}$ substrate depth dries out faster than either the 7.0 - or the $10.0-\mathrm{cm}$ depths (Fig. 4).

This greater water availability at the deeper substrate depths may explain why the $7.0-\mathrm{cm}$ and $10-\mathrm{cm}$ substrate depths had higher AC than the 4.0-cm depth. Another factor may be the result of substrate temperature differences. Boivin et al. (2001) found that shallower extensive green roof substrates experienced much more severe temperature fluctuations than deeper substrates. During the growing season, shallower substrates will likely experience higher soil temperatures, which in turn will influence plant growth (Bouma et al., 1997; Prasad et al., 2000). This is exacerbated by the fact that lower AC of the $4.0-\mathrm{cm}$ substrate depth exposes more substrate to direct sun resulting in higher substrate temperatures. In addition, some species are more suited for these temperature or water fluctuations than others. Durhman et al. (2007) found that $S$. album was the only species of 25 that exceeded $1.5 \mathrm{~cm}^{2}$ of growth per day at a substrate depth of $2.5 \mathrm{~cm}$ (1.0 in). At a substrate depth of $5.0 \mathrm{~cm}$ (2.0 in) and 7.5 $\mathrm{cm}$ (3.0 in), this increased to three species and eight species, respectively.

Chlorophyll fluorescence data did not follow the same pattern as AC and substrate moisture content. Mean $\mathrm{F}_{\mathrm{v}} / \mathrm{F}_{\mathrm{m}}$ values were not significantly different at $0.795,0.779$, and 0.781 for substrate depths of $4.0 \mathrm{~cm}, 7.0 \mathrm{~cm}$, and $10 \mathrm{~cm}$, respectively. There were also very few differences between species within the same depth (data not shown). This may be because measurements for chlorophyll fluorescence occurred during the third and fourth growing seasons only, whereby three (Sedum cauticola 'Lidakense', Sedum ochroleucum, and Sedum sediforme) of the 12 initial species had zero AC (i.e., no plants to take measurements on). Had chlorophyll fluorescence data been taken during the first growing season, perhaps noticeable differences would have been detected between species that ultimately survived the 4-year study and those that did not. In addition, at individual measuring 


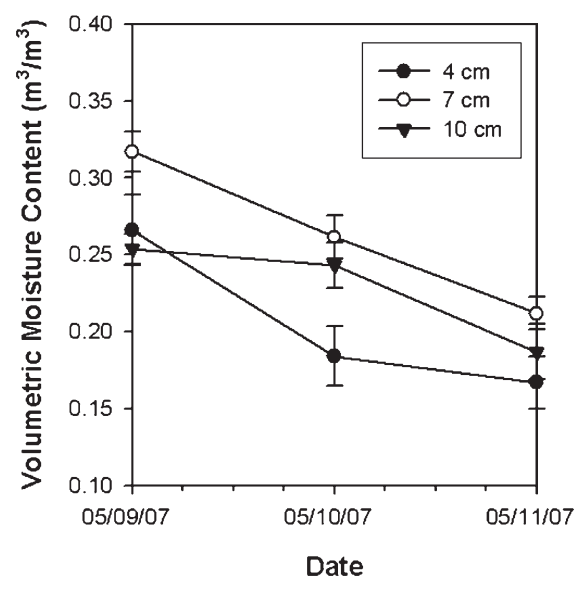

Fig. 4. Substrate volumetric moisture content $\left(\mathrm{m}^{3} /\right.$ $\left.\mathrm{m}^{3}\right) \pm$ SEs for a selected 3-d period after a 22.1$\mathrm{mm}$ rain event at three substrate depths (4.0, 7.0 , and $10.0 \mathrm{~cm}$ ).

times, which represent the driest portions of the growing season (18 June 2007, 2 Aug. 2007, and 20 Aug. 2008), mean chlorophyll fluorescence values of individual species never fell below 0.60 , indicating very little, if any, stress to the photosynthetic system (Ritchie, 2006). Other research has established the same trend for many species in this genus. In a controlled greenhouse watering study, Durhman et al. (2006) found that three Sedum species maintained active photosynthetic capacity for at least $88 \mathrm{~d}$ without water. This may at least partially explain why Sedum species are such good candidates for extensive green roofs.

These results show the importance of substrate depth on plant performance as well as long-term evaluation of species. Of the substrate depths and species evaluated in this article, substrate depths of at least $7.0 \mathrm{~cm}$ are highly recommended. AC was significantly greater at this substrate depth relative to the shallower depth of $4.0 \mathrm{~cm}$. Species exhibiting the greatest AC at all substrate depths were $S$. floriferum, S. sexangulare, S. spurium 'John Creech', and S. stefco. In general, species that are less suitable are $S$. 'Angelina', $S$. cauticola 'Lidakense', S. ewersii, S. ochroleucum, and $S$. reflexum 'Blue Spruce'.

\section{Literature Cited}

Baumann, N. 2006. Ground-nesting birds on green roofs in Switzerland. Preliminary observations. Urban Habitats 4:37-50.

Boivin, M., M. Lamy, A. Gosselin, and B. Dansereau. 2001. Effect of artificial substrate depth on freezing injury of six herbaceous perennials grown in a green roof system. HortTechnology 11:409-412.

Bouma, T.J., K.L. Nielsen, D.M. Eissenstat, and J.P. Lynch. 1997. Estimating respiration of roots in soil: Interactions with soil $\mathrm{CO}_{2}$, soil temperature and soil water content. Plant Soil 195:221-232.

Brenneisen, S. 2006. Space for urban wildlife: Designing green roofs as habitats in Switzerland. Urban Habitats 4:27-36.

Cathey, H.M. 1990. USDA plant hardiness zone map. USDA Agric. Res. Serv. Misc. Publ. 1475.
Carter, T. and C.R. Jackson. 2007. Vegetated roofs for stormwater management at multiple spatial scales. Landsc. Urban Plan. 80:84-94.

Clark, C., P. Adriaens, and F.B. Talbot. 2008. Green roof valuation: A probabilistic economic analysis of environmental benefits. Environ. Sci. Technol. 42:2155-2161.

Dunnett, N. and N. Kingsbury. 2004. Planting green roofs and living walls. Timber Press, Inc., Portland, OR.

Durhman, A.K., D.B. Rowe, and C.L. Rugh. 2006. Effect of watering regimen on chlorophyll fluorescence and growth of selected green roof plant taxa. HortScience 41:1623-1628.

Durhman, A.K., D.B. Rowe, and C.L. Rugh. 2007. Effect of substrate depth on initial coverage, and survival of 25 succulent green roof plant taxa. HortScience 42:588-595.

Emilsson, T. 2008. Vegetation development on extensive vegetated green roofs. Influence of substrate composition, establishment method and species mix. Ecol. Eng. 33:265-277.

Emilsson, T. and K. Rolf. 2005. Comparison of establishment methods for extensive green roofs in southern Sweden. Urban Forestry \& Urban Greening 3:103-111.

FLL (Forschungsgesellschaft Landschaftsentwicklung Landschaftsbau). 1995. Guidelines for the planning, execution and upkeep of green-roof sites. Forschungsgesellschaft Landschaftsentwicklung Landschaftsbau, Bonn, Germany.

Getter, K.L. and D.B. Rowe. 2006. The role of extensive green roofs in sustainable development. HortScience 41:1276-1285.

Getter, K.L. and D.B. Rowe. 2007. Effect of substrate depth and planting season on sedum plug survival on green roofs. J. Environ. Hort. 25:95-99.

Getter, K.L. and D.B. Rowe. 2008. Media depth influences Sedum green roof establishment. Urban Ecosyst. 11:361-372.

Getter, K.L., D.B. Rowe, and J.A. Andresen. 2007. Quantifying the effect of slope on extensive green roof stormwater retention. Ecol. Eng. 31:225-231.

Gravatt, D.A. 2003. Crassulacean acid metabolism and survival of asexual propagules of Sedum wrightii. Photosynthetica 41:449-452.

Green Roofs for Healthy Cities. 2008. Final report, Green Roof Industry Survey 2007. Green Roofs for Healthy Cities, Toronto, Ontario, Canada.

Hilten, R.N., T.M. Lawrence, and E.W. Tollner. 2008. Modeling stormwater runoff from green roofs with HYDRUS-1D. J. Hydrol. 358:288293.

Jarrett, A.R. and R.D. Berghage. 2008. Annual and individual green roof stormwater response models. In: Proc. of 6th North American Green Roof Conference: Greening Rooftops for Sustainable Communities, Baltimore, MD, 30 April-2 May 2008. The Cardinal Group. Toronto, Canada.

Kircher, W. 2004. Annuals and Sedum-cuttings in seed-mixtures for extensive roof gardens. Acta Hort. 643:301-303.

Kluge, M. 1977. Is Sedum acre L. a CAM plant? Oceologia 29:77-83.

Köhler, M. 2006. Long-term vegetation research on two extensive green roofs in Berlin. Urban Habitats 4:3-26.

Kosareo, L. and R. Ries. 2007. Comparative environmental life cycle assessment of green roofs. Build. Environ. 42:2606-2613.

Lee, K.S. and J. Kim. 1994. Changes in crassulacean acid metabolism (CAM) of Sedum plants with special reference to soil moisture conditions. J. Plant Biol. 37:9-15.
Liesecke, H.J. 1998. Das retentionsvermögen von dachbegrünungen [Water retention capacity of vegetated roofs]. Stadt und Grün 47:46-53.

MacDonagh, L.P., N.M. Hallyn, and S. Rolph. 2006. Midwestern USA plant communities + design $=$ Bedrock bluff prairie greenroofs. In: Proc. of 4th North American Green Roof Conference: Greening Rooftops for Sustainable Communities, Boston, MA, 11-12 May 2006. The Cardinal Group. Toronto, Canada.

Maxwell, K. and G.N. Johnson. 2000. Chlorophyll fluorescence-A practical guide. J. Expt. Bot. 51:659-668.

Monterusso, M.A., D.B. Rowe, and C.L. Rugh. 2005. Establishment and persistence of Sedum spp. and native taxa for green roof applications. HortScience 40:391-396.

Nagase, A. and N. Dunnett. 2008. Experiments in plant selection for extensive green roofs: Performance of annual plant species and the amount of water runoff from different vegetation types. In: Proc. of 6th North American Green Roof Conference: Greening Rooftops for Sustainable Communities, Baltimore, MD30 April-2 May 2008. The Cardinal Group. Toronto, Canada.

Oberndorfer, E., J. Lundholm, B. Bass, R.R. Coffman, H. Doshi, N. Dunnett, S. Gaffin, M. Köhler, K.K.Y. Liu, and D.B. Rowe. 2007. Green roofs as urban ecosystems: Ecological structures, functions, and services. Bioscience 57:823-833.

Prasad, P.V., P.W. Craufurd, and R.J. Summerfield. 2000. Effect of high air and soil temperature on dry matter production, pod yield and yield components of groundnut. Plant Soil 222:231-239.

Ritchie, G. 2006. Chlorophyll fluorescence: What is it and what do the numbers mean? p. 34-43. In: USDA Forest Service Proceedings RMRSP-43. U.S. Department of Agriculture, Forest Service, Rocky Mountain Research Station, Fort Collins, CO.

Rowe, D.B., C.L. Rugh, and A.K. Durhman. 2006. Assessment of substrate depth and composition on green roof plant performance. In: Proc. of 4th North American Green Roof Conference: Greening Rooftops for Sustainable Communities, Boston, MA, 11-12 May 2006, The Cardinal Group, Toronto, Canada.

Sailor, D.J. 2008. A green roof model for building energy simulation programs. Energy Build. 40:1466-1478.

Santamouris, M., C. Pavlou, P. Doukas, G. Mihalakakou, A. Synnefa, A. Hatzibiros, and P. Patargias. 2007. Investigating and analysing the energy and environmental performance of an experimental green roof system installed in a nursery school building in Athens, Greece. Energy 32:1781-1788.

Snodgrass, E. and L. Snodgrass. 2006. Green roof plants: A resource and planting guide. Timber Press, Inc., Portland, OR.

Stephenson, R. 2002. Sedum: Cultivated stonecrop. Timber Press, Inc., Portland, OR.

Takebayashi, H. and M. Moriyama. 2007. Surface heat budget on green roof and high reflection roof for mitigation of urban heat island. Build. Environ. 42:2971-2979.

Teeri, J.A., M. Turner, and J. Gurevitch. 1986. The response of leaf water potential and crassulacean acid metabolism to prolonged drought in Sedum rubrotinctum. Plant Physiol. 81:678-680.

Underwood, A.J. 1998. Experiments in ecology: Their logical design and interpretation using analysis of variance. University Press, Cambridge, UK.

Van Renterghem, T. and D. Botteldooren. 2008. Numerical evaluation of sound propagating over green roofs. J. Sound Vibrat. 317:781-799. 
VanWoert, N.D., D.B. Rowe, J.A. Andresen, C.L. Rugh, R.T. Fernandez, and L. Xiao. 2005 a. Green roof stormwater retention: Effects of roof surface, slope, and media depth. J. Environ. Qual. 34:1036-1044.

VanWoert, N.D., D.B. Rowe, J.A. Andresen, C.L. Rugh, and L. Xiao. 2005b. Watering regime and green roof substrate design affect Sedum plant growth. HortScience 40:659-664.

Waite, S. 2000. Statistical ecology in practice: A guide to analyzing environmental and ecological field data. Prentice Hall, Harlow, UK.

Wilson, W.J. 1960. Inclined point quadrats. New Phytol. 59:1-8.
Wolf, D. and J.T. Lundholm. 2008. Water uptake in green roof microcosms: Effects of plant species and water availability. Ecol. Eng. 33:179 186.

Yang, J., Q. Yu, and P. Gong. 2008. Quantifying air pollution removal by green roofs in Chicago. Atmos. Environ. 42:7266-7273. 